\title{
PENGARUH NILAI PENDIDIKAN KARAKTER TERHADAP DISIPLIN SISWA KELAS XI SMK ISLAM SUDIRMAN TAHUN AJARAN 2018/2019
}

\author{
Feri Sulis Diana' ${ }^{1}$ Setyorini² Sapto Irawan ${ }^{3}$ \\ Email: 132015057@student.uksw.edu1 setyorini@uksw.edu ${ }^{2}$ \\ sapto@staff.uksw.edu ${ }^{3}$ \\ Progam Studi Bimbingan dan Konseling Fakultas Keguruan dan Ilmu Pendidikan \\ Universitas Kristen Satya Wacana ${ }^{1,2,3}$
}

\begin{abstract}
Abstrak
Penelitian ini bertujuan untuk mengetahui pengaruh yang signifikan antara nilai pendidikan karakter terhadap disiplin siswa. Subjek penelitian ini yaitu kelas XI SMK Islam Sudirman yang berjumlah 117 peserta didik. Teknik pengambilan sampel menggunakan teknik probability sampling dengan teknik total sampel, sampel yang ditetapkan adalah semua populasi kelas XI SMK Islam Sudirman yang berjumlah 117 peserta didik. Jenis penelitian ini termasuk kedalam penelitian inferensial. Teknik pengambilan data menggunakan skala nilai pendidikan karakter berdasarkan 18 nilai-nilai pendidikan karakter dan skala disiplin siswa berdasarkan teori Hurlock (2002). Teknik analisis data yang digunakan yaitu regresi linier sederhana dengan bantuan SPSS for windows 21.0. Berdasarkan hasil analisis data diperoleh nilai dari $R$ Squarenya adalah 0,082 yang berarti 8,2 \% memberikan pengaruh terhadap disiplin siswa. Berdasarkan data Anova dapat diketahui hasil nilai $\mathrm{F}$ hitung $=10,285$ dengan tingkat probabilitas signifikansi 0,002 $<0.05$ maka dapat dikatakan juga bahwa terdapat pengaruh secara simultan nilai pendidikan karakter terhadap disiplin siswa. Jadi dapat disimpulkan bahwa hasil penelitian menyatakan ada pengaruh positif yang signifikan antara nilai pendidikan karakter terhadap disiplin siswa kelas XI SMK Islam Sudirman tahun ajaran 2018/2019.
\end{abstract}

Kata Kunci : Nilai pendidikan Karakter; Disiplin Siswa

\begin{abstract}
This study aims to determine the significant effect of the value of character education on student discipline. The subject of this study was the XI class of Sudirman Islamic Vocational School, which amounted to 117 students. The sampling technique uses probability sampling techniques with a total sample technique, the sample set is all the population of the XI class of Sudirman Islamic Vocational School, amounting to 117 students. This type of research is included in inferential research. The data collection technique uses the character education value scale based on 18 character education values and student discipline scales based on the theory of Hurlock (2002). The data analysis technique used is simple linear regression with the help of SPSS for Windows 21.0. Based on the results of data analysis, the value of the $R$ Squares is 0.082 which means $8.2 \%$ has an influence on student discipline. Based on Anova data, it can be seen that the results of $F$ count $=10.285$ with a significance probability level of $0.002<0.05$, it can be said that there is a simultaneous influence of the value of character education on student discipline. So it can be concluded that the results of the study state that there is a significant positive influence between the value of character education on the discipline of XI students in the Sudirman Islamic Vocational High School 2018/2019.
\end{abstract}

Keywords: Value of Character Education; Student Discipline

\section{PENDAHULUAN}

Sumber daya manusia yang unggul

dan berkualitas merupakan aset bagi negara agar menjadi lebih maju. Dalam menyiapkan sumber daya manusia yang unggul dan berkualitas tentu tidak bisa lepas dari pendidikan. Pendidikan merupakan usaha yang dilakukan oleh manusia

untuk

meningkatkan

kesejahteraan hidupnya, yang berlangsung sepanjang hayat. Siswa merupakan sumber daya manusia yang harus dikembangkan melalui pendidikan.

Oleh karena itu, peningkatan kualitas sumber daya manusia sejak dini 
merupakan hal penting yang harus dipikirkan secara sungguh-sungguh.

Di Indonesia, dalam UndangUndang No. 20 Tahun 2003 tentang Sistem Pendidikan Nasional pasal 3 dijelaskan bahwa pendidikan nasional berfungsi untuk mengembangkan kemampuan dan membentuk watak serta peradaban bangsa yang bermartabat dalam rangka mencerdaskan kehidupan bangsa, bertujuan untuk berkembangnya potensi peserta didik agar menjadi manusia yang beriman dan bertaqwa kepada Tuhan yang Maha Esa, berakhlak mulia, sehat, berilmu, cakap, kreatif, madiri dan menjadi warga negara yang demokratis serta bertanggung jawab.

Dalam hal tersebut tampak bahwa pendidikan bukan sekedar berfungsi sebagai media untuk mengembangkan kemampuan semata, melainkan juga berfungsi untuk membentuk karakter peradaban bangsa yang bermartabat. Karakter yang dimiliki oleh generasi muda merupakan aspek penting dalam meningkatkan kualitas sumber daya manusia, karena karakter yang baik dapat menentukan kemajuan suatu bangsa.

Karakter dapat dikatakan sebagai nilai-nilai dan sikap hidup yang positif, yang dimiliki seseorang sehingga mempengaruhi tingkah laku, cara berpikir dan bertindak orang itu, dan akhirnya menjadi tabiat hidupnya (Paul Suparno, 2015). Menurut Thomas Lickona orang yang berkarakter sebagai sifat yang alami seseorang dalam merespons situasi secara bermoral, yang dimanisfestasikan dalam tindakan nyata melalui tingkah laku yang baik, jujur, bertanggung jawab, menghormati orang lain dan karakter mulia lainnya (Muslich, 2011).

Di lembaga pendidikan, guru menerapkan nilai pendidikan karakter di sekolah melalui kegiatan sekolah maupun mata pelajara. Thomas Lickona (2004) mendefinisikan pendidikan karakter sebagai upaya yang dirancang secara sengaja untuk memperbaiki karakter para siswa. Pendidikan karakter bertujuan untuk membantu siswa agar mengalami, memperoleh, dan memiliki karakter kuat yang diinginkan.

Pendidikan karakter yang diterapkan di sekolah mengacu pada 18 nilai karakter yang meliputi, religius, jujur, toleransi, disiplin, kerja keras, kreatif, mandiri, demokratis, rasa ingin tahu, semangat kebangsaan, cinta tanah air, menghargai prestasi, komunikatif, cinta damai, gemar membaca, peduli lingkungan, peduli sosial dan tanggung jawab.

Jika nilai pendidikan karakter yang diterapkan dan dikembangkan disekolah dapat berhasil, maka peserta didik akan 
mempunyai karakter yang baik sehingga peserta didik akan lebih menekankan disiplin pada dirinya. Selain itu, kesuksesan seseorang tidak semata-mata ditentukan oleh pengetahuan dan keterampilan teknis, melainkan juga oleh karakter yang dimiliki. Orang yang memiliki karakter yang baik pasti akan menerapkan kedisiplinan pada dirinya.

Dalam era moderen ini dengan adanya kemajuan teknologi yang pesat, karakter siswa disinyalir kian turun akibat melemahnya nilai pendidikan karakter dalam diri siswa. Karakter yang santun, berbudi pekerti, ramah dan gotong royong pelan-pelan mulai menurun. Seperti yang diungkapkan oleh Thomas Lickona bahwa ada sepuluh tanda zaman yang kini terjadi tetapi harus diwaspadai karena dapat membawa bangsa menuju jenjang kehancuran.

Sepuluh tanda zaman itu adalah meningkatnya kekerasan di kalangan remaja atau masyarakat, penggunaan bahasa dan kata-kata yang memburuk, pengaruh geng dalam tindak kekerasan, meningkatnya perilaku merusak diri seperti penggunaan narkoba, alkohol dan seks bebas, semakin kaburnya pedoman moral baik dan buruk, menurunnya etos kerja, semakin rendahnya rasa hormat kepada orang tua dan guru, rendahnya rasa tanggung jawab individu dan kelompok, membudayanya kebohongan, dan adanya rasa saling curiga (Gunawan, 2012). Maka dari itu, nilai pendidikan karakter harus diterapkan dan dikembangkan agar dapat menciptakan generasi muda yang berkualitas dan berkarakter baik.

Disetiap lembaga pendidikan selain mengajarkan dan menerapkan nilai pendidikan karakter, pendidik juga menekankan adanya kedisiplinan yang harus ditaati oleh para siswa disekolah maupun di luar sekolah. Seseorang yang mempunyai karakter baik tentunya selalu mendisiplinkan dirinya sesuai dengan peraturan yang sudah ditetapkan dalam suatu organisasi atau lembaga. Meskipun sekolah sudah menekankan adanya kedisiplinan yang harus ditaati oleh peserta didik, namun dalam kenyataannya masih ada beberapa siswa yang kurang disiplin.

Disiplin merupakan upaya yang dilakukan untuk mengendalikan diri dan sikap mental individu atau masyarakat dalam mengembangkan kepatuhan dalam ketaatan terhadap peraturan dan tata tertib berdasarkan dorongan dan kesadaran yang muncul dari dalam hatinya (Tu'u, 2004).

SMK Islam Sudirman merupakan sekolah yang mengajarkan pendidikan karakter serta menekankan kedisiplinan 
kepada siswanya. Pendidik mengajarkan pendidikan karakter sesuai dengan 18 nilai pendidikan karakter yang diberikan melalui mata pelajaran seperti mata pelajaran Agama, Kewarganegaraan, Bahasa Indonesia, Olahraga dan juga layanan BK.

Selain itu, aplikasi pendidikan karakter yang ada di SMK Islam Sudirman yang ada di sekolah seperti melakukan literasi selama 15 menit, setiap pagi membaca asmaul husna sebelum pelajaran di mulai, sholat dhu'ha, cek kerapian seragam, dan juga melaksanakan upacara setiap hari senin dan juga hari nasional. Pendidikan karakter diberikan dengan tujuan agar siswa dapat mempunyai sikap dan tingkah laku yang baik dalam kehidupan sehari-hari serta dapat menjadi pribadi yang disiplin dengan mentaati peraturan yang ada.

Namun demikian, meskipun sekolah sudah memberikan dan mengaplikasikan nilai pendidikan karakter ternyata masih ada beberapa siswa yang kurang disiplin. Berdasarkan data administrasi dan presensi siswa di SMK Islam Sudirman pada tahun ajaran 2017/2018 masih ada beberapa siswa yang melanggar tata tertib di sekolah. Sebagian besar pelanggaran yang dilakukan oleh siswa adalah terlambat datang ke sekolah, merokok, tidak berangkat sekolah tanpa ijin dan juga tidak memakai seragam dengan rapi yang sesuai dengan peraturan yang diterapkan di sekolah. Selain itu, dari hasil presensi siswa selama tahun ajaran 2017/2018 terdapat sekitar 10-15\% siswa yang tidak berangkat sekolah tanpa ijin dari total 315 siswa di SMK Islam Sudirman.

\section{KAJIAN PUSTAKA}

\section{Disiplin}

Istilah disiplin berasal dari bahasa latin "disciplina" yang merujuk pada kegiatan belajar mengajar. Istilah tersebut sangat dekat dengan istilah dalam bahasa Inggris diciple yang berarti mengikuti orang untuk belajar dibawah pengawasan seseorang pemimpin (Mac Millan Dictionary dalam Tulus Tu'u , 2004).

Maman Rahman mengartikan disiplin sebagai upaya mengendalikan diri dan sikap mental individu atau masyarakat dalam mengembangkan kepatuhan dan ketaatan terhadap peraturan dan tata tertib berdasarkan dorongan dan kesadaran yang muncul dari dalam hatinya (Tu'u, 2004). Tu'u (2004) merumuskan bahwa disiplin adalah sebuah upaya untuk mengikuti dan menaati peraturan, nilai, dan hukum yang berlaku, yang muncul karena adanya kesadaran diri bahwa ketaatan itu berguna bagi kebaikan dan keberhasilan 
dirinya. Selanjutnya Imron (2011) mendefinisikan disiplin adalah suatu keadaan di mana sesuatu itu berada dalam keadaan tertib, teratur dan semestinya, serta tidak ada suatu pelanggaranpelanggaran baik secara langsung atau tidak langsung.

Berdasarkan pendapat dari para ahli, penulis dapat menyimpulkan bahwa disiplin merupakan sikap seseorang untuk mentaati aturan atau tata tertib yang berlaku di dalam suatu organisasi berdasarkan kesadaran yang ada pada dirinya untuk membentuk perilaku sesuai dengan nilai-nilai yang ditentukan.

Disiplin terdapat aspek-aspek diantara satu dengan yang lain saling mendukung. Hurlock (2002), menyatakan bahwa aspek-aspek disiplin meliputi :

1. Peraturan : Peraturan adalah pola yang ditetapkan untuk tingkah laku. Pola tersebut mungkin diterapkan orang tua, guru atau teman bermain. Tujuannya ialah membekali anak dengan pedoman perilaku yang disetujui dalam situasi tertentu.

2. Hukuman : Hukuman diartikan sebagai suatu ganjaran yang diberikan pada seseorang karena melakukan kesalahan, perlawanan atau pelanggaran. Hukuman digunakan supaya anak tidak mengulangi perbuatan yang salah.

3. Penghargaan : Istilah penghargaan berarti tiap bentuk penghargaan untuk suatu hasil yang baik. penghargaan tidak perlu berbentuk materi, tetapi dapat berupa katakata pujian, senyuman atau tepukan di panggung. Penghargaan berfungsi supaya anak mengetahui bahwa tindakan tersebut baik dan anak akan termotivasi untuk belajar berperilaku yang lebih baik lagi.

4. Konsistensi : Konsistensi dapat diartikan sebagai tingkat keseragaman atau stabilitas, yaitu suatu kecenderungan menuju kesamaan. Konsistensi harus ada dalam peraturan, hukuman dan penghargaan. Tujuan dari pada konsistensi adalah anak akan terlatih dan terbiasa dengan segala sesuatu yang tetap sehingga mereka akan termotivasi untuk melakukan hal yang benar dan menghindari hal yang salah. Aspek-aspek disiplin tersebut diharapkan mampu mendidik anak untuk berperilaku sesuai standar yang ditetapkan kelompok sosial mereka.

Disiplin diperlukan oleh siapapun dan dimanapun. Hal itu disebabkan dimanapun seseorang berada, disana 
selalu ada peraturan atau tata tertib. Jadi, manusia mustahil hidup tanpa disiplin. Manusia memerlukan disiplin dalam hidupnya dimanapun berada. Apabila manusia mengabaikan disiplin, akan menghadapi banyak masalah dalam kehidupan sehari-hari. Oleh karena itu, perilaku hidupnya tidak sesuai dengan peraturan yang berlaku di tempat manusia berada dan yang menjadi harapan. Dalam kerangka pembangunan dan kemajuan bangsa dan negara, disiplin sangat penting dan menentukan. Karena kemajuan pembangunan, martabat dan kesejahteraan bangsa tercapai karena warga masyarakat memiliki disiplin yang baik.

Ada beberapa faktor yang dapat berpengaruh pada pembentukan disiplin individu yang dikemukakan oleh Semiawan (2009) yaitu :

1. Hubungan emosional yang kualitatif dan kondusif sebagai landasan untuk membentuk disiplin.

2. Keteraturan yang konsisten dan berkesinambungan dalam menjalankan berbagai aturan.

3. Keteladanan yang berawal dari perbuatan kecil dalam ketaatan disiplin di rumah, seperti belajar tepat waktu.

4. Lingkungan yang berfungsi untuk pengembangan disiplin, baik lingkungan rumah, sekolah dan masyarakat.

5. Ketergantungan dan kewibawaan yang harus dimiliki oleh setiap guru dan orang tua untuk memahami dinamisme perkembangan anak.

\section{Nilai Pendidikan Karakter}

Nilai berasal dari bahasa latin vale're yang artinya berguna, mampu akan berdaya, berlaku, sehingga nilai diartikan sebagai sesuatu yang dipandang baik, bermanfaat dan paling benar menurut keyakinan seseorang atau sekelompok orang (Sutarjo : 2012). Sedangkan menurut Muslich (2011) Nilai adalah kualitas suatu hal yang menjadikan hal itu dapat disukai, diinginkan, berguna, dihargai, dan dapat menjadi objek kepentingan. Selanjutnya Wicaksono (2015) mengatakan bahwa nilai merupakan kadar relasi positif antara suatu hal terhadap seseorang. Nilai adalah sesuatu atau hal-hal yang berguna bagi kemanusiaan. Nilai berkaitan erat dengan kebaikan yang ada pada sesuatu hal. Nilai dapat membantu kita menyadari, mengakui, mendalami dan memahami hakikat kaitan antara nilai satu dengan yang lainnya serta peranan dan kegunaannya bagi kehidupan. Thomas Lickona (2004) mendefinisikan pendidikan karakter sebagai upaya yang dirancang secara sengaja untuk 
memperbaiki karakter para siswa

(Muchlas Samani dan Hariyanto, 2011).

Selanjutnya menurut Muchlas Samani dan Hariyanto (2011) Pendidikan karakter merupakan proses pemberian tuntunan kepada peserta didik untuk menjadi manusia seutuhnya yang berkarakter dalam dimensi hati, pikir, raga, serta rasa dan karsa. Pendidikan karakter dapat dimaknai sebagai pendidikan nilai, pendidikan budi pekerti, pendidikan moral, pendidikan watak, yang bertujuan mengembangkan kemampuan peserta didik untuk memberikan keputusan baik buruk, memelihara apa yang baik, dan mewujudkan kebaikan itu dalam kehidupan sehari-hari dengan sepenuh hati.

Pendidikan karakter dapat pula dimaknai sebagai upaya yang terencana untuk menjadikan peserta didik mengenal, peduli dan menginternalisasi nilai-nilai sehingga peserta didik berperilaku sebagai insan kamil. Jadi, dapat disimpulkan bahwa nilai pendidikan karakter merupakan segala sesuatu yang bermanfaat sehingga dapat merubah, memperbaiki sikap serta tingkah laku seseorang agar dapat berperilaku yang baik sehingga dapat berguna bagi kehidupan.
Menurut Kementrian Pendidikan Nasional (2010), tujuan pendidikan karakter yaitu Mengembangkan potensi kalbu/nurani/afektif peserta didik sebagai manusia dan warga negara yang memiliki nilai-nilai budaya dan karakter bangsa, Mengembangkan kebiasaan dan perilaku peserta didik yang terpuji dan sejalan dengan nilai-nilai universal dan tradisi budaya bangsa yang religius, menanamkan jiwa kepemimpinan dan tanggung jawab peserta didik sebagai generasi penerus bangsa, mengembangkan kemampuan peserta didik untuk menjadi manusia yang mandiri, kreatif dan berwawasan kebangsaan, mengembangkan lingkungan kehidupan sekolah sebagai lingkungan belajar yang aman, jujur, penuh kreativitas dan persahabatan, serta dengan rasa kebangsaan yang tinggi dan penuh kekuatan (dignity).

Dari berbagai penjelasan diatas, dapat disimpulkan bahwa tujuan dari pendidikan karakter adalah membentuk, menanamkan, memfasilitasi, dan mengembangkan nilai-nilai positif pada anak sehingga menjadi pribadi yang unggul dan bermartabat (Agus Zaenul Fitri, 2012).. 


\section{METODE PENELITIAN}

Jenis penelitian ini adalah inferensial dengan menggunakan teknik analisis regresi linier sederhana. Populasi yang ditentukan oleh peneliti adalah peserta didik kelas XI SMK Islam Sudirman yang berjumlah 117 peserta didik. Peneliti memilih populasi kelas XI karena pada umumnya siswa kelas XI merupakan kelas dimana para siswa sudah mulai beranjak dewasa dan mempunyai sikap kurang disiplin disekolah. Dalam penelitian ini teknik pengambilan sampel menggunakan teknik probability sampling dengan teknik total sampling. Sampel yang ditetapkan adalah kelas XI SMK Islam Sudirman yang jumlahnya 117 siswa. Peneliti memilih teknik total sampling karena semua anggota populasi di kelas XI SMK Islam Sudirman digunakan sebagai sampel. Teknik pengumpulan data yang di gunakan dalam penelitian ini berupa sekala nilai pendidikan karakter dan skala disiplin.

Uji validitas instrument mengacu pada teori Azwar (2012) dengan koefisien validitas berada di atas 0.20 . Uji reliabilitas mengacu pada teori George \& Mallery (1995) dengan hasil kedua skala memiliki koefisien reliabilitas $>0.9$ dan berada pada kategori reliabilitas sangat bagus. Teknik analisis data dalam penelitian kuantitatif menggunakan statistik. Teknik analisis yang digunakan dalam penelitian ini adalah menggunakan teknik analisis regresi linier sederhana dengan bantuan program SPSS for Windows 21.0.

\section{HASIL DAN PEMBAHASAN}

Penelitian yang dilakukan di SMK Islam Sudirman, mencakup sampel sebesar 117 siswa kelas XI, dengan perincian sebagai berikut :

Tabel 1. Rincian Jumlah Siswa

\begin{tabular}{|l|l|c|l|}
\hline Kelas & Perempuan & Laki-Laki & Jumlah \\
\hline XI TMI & 0 & 36 & 36 \\
\hline XI Farm & 2 & 1 & 3 \\
\hline $\begin{array}{l}\text { XI } \\
\text { Listrik }\end{array}$ & 0 & 14 & 14 \\
\hline $\begin{array}{l}\text { XI TKR } \\
1\end{array}$ & 0 & 35 & 35 \\
\hline $\begin{array}{l}\text { XI TKR } \\
2\end{array}$ & 0 & 29 & 29 \\
\hline Jumlah keseluruhan dat dilihat data
\end{tabular}

subjek penelitian yang terdiri dari kelas XI TMI berjumlah 36 peserta didik lakilaki, kelas XI Farmasi berjumlah 3 peserta didik yang terdiri dari 1 laki-laki dan 2 perempuan, kelas XI Listrik berjumlah 14 peserta didik laki-laki, kelas XI TKR 1 berjumlah 35 peserta didik laki-laki dan kelas XI TKR 2 berjumlah 29 peserta didik laki-laki. Jumlah seluruh subjek penelitian yaitu ada 117 peserta didik kelas XI SMK Islam Sudirman. 


\section{Analisis deskriptif}

Hasil analisis deskriptif nilai pendidikan karakter diketahui sebagai berikut :

Tabel 2. Distribusi Frekuensi Nilai Pendidikan Karakter

\begin{tabular}{|l|l|l|l|}
\hline Kategori & Interval & $\begin{array}{l}\text { Frekuen } \\
\text { si }\end{array}$ & Presentase \\
\hline $\begin{array}{l}\text { Sangat } \\
\text { Baik }\end{array}$ & $>231$ & 0 & $0 \%$ \\
\hline Baik & $187-230$ & 42 & $35,89 \%$ \\
\hline $\begin{array}{l}\text { Cukup } \\
\text { Baik }\end{array}$ & $143-186$ & 75 & $64,10 \%$ \\
\hline $\begin{array}{l}\text { Kurang } \\
\text { Baik }\end{array}$ & $99-142$ & 0 & $0 \%$ \\
\hline $\begin{array}{l}\text { Tidak } \\
\text { Baik }\end{array}$ & $55-98$ & 0 & $0 \%$ \\
\hline Jumlah & 117 & $100 \%$ \\
\hline
\end{tabular}

Berdasarkan tabel 2 diketahui

bahwa variabel nilai pendidikan karakter kelas XI SMK Islam Sudirman tahun ajaran 2018/2019 yang berjumlah 117 siswa dapat diperoleh hasil sebesar 0\% dengan jumlah 0 siswa berada pada kategori sangat baik. Sebesar 35,89\% dengan jumlah 42 siswa berada pada kategori baik. Sebesar 64,10\% dengan jumlah 75 siswa berada pada kategori cukup baik. Sebesar $0 \%$ dengan jumlah 0 siswa pada kategori kurang baik dan $0 \%$ dengan jumlah 0 siswa berada pada kategori tidak baik.

Tabel 3. Distribusi Frekuensi Disiplin

\begin{tabular}{|l|l|l|l|}
\hline Kategori & Interval & Frekuensi & Presentase \\
\hline $\begin{array}{l}\text { Sangat } \\
\text { Baik }\end{array}$ & $>136$ & 53 & $45,29 \%$ \\
\hline Baik & $\begin{array}{l}110- \\
135\end{array}$ & 44 & $37,60 \%$ \\
\hline $\begin{array}{l}\text { Cukup } \\
\text { Baik }\end{array}$ & $84-109$ & 17 & $14,52 \%$ \\
\hline
\end{tabular}

\begin{tabular}{|l|l|l|l|}
\hline $\begin{array}{l}\text { Kuraung } \\
\text { Baik }\end{array}$ & $58-83$ & 3 & $2,56 \%$ \\
\hline $\begin{array}{l}\text { Tidak } \\
\text { Baik }\end{array}$ & $32-57$ & 0 & $0 \%$ \\
\hline Jumlah & & 117 & $100 \%$ \\
\hline
\end{tabular}

Berdasarkan tabel 3 diketahui bahwa variabel disiplin siswa kelas XI SMK Islam Sudirman tahun ajaran 2018/2019 yang berjumlah 117 siswa dapat diperoleh hasil sebesar 45,29\% dengan jumlah 53 siswa berada pada kategori sangat tinggi. Sebesar 37,60 \% dengan jumlah 44 siswa berada pada kategori tinggi. Sebesar 14,52 \% dengan jumlah 17 siswa berada pada kategori sedang. Sebesar 2,56\% dengan jumlah 3 siswa pada kategori rendah dan $0 \%$ dengan jumlah 0 siswa berada pada kategori sangat rendah.

\section{Uji Hipotesis}

Untuk mengetahui pengaruh nilai pendidikan karakter terhadap disiplin, maka pengolahan data dilakukan dengan menggunakan teknik analisis regresi linier sederhana dengan bantuan SPSS 21.0 for windows yang memakai taraf signifikansi 5\% adalah sebagai berikut :

Tabel 4. Analisis Regresi Linier

\begin{tabular}{|l|l|l|l|l|}
\hline \multicolumn{3}{|l|}{ Model Summary } \\
\hline Model & R & R Square & $\begin{array}{l}\text { Adjusted R } \\
\text { Square }\end{array}$ & $\begin{array}{l}\text { Std. Error of } \\
\text { the Estimate }\end{array}$ \\
\hline 1 &, $287^{\text {a }}$ &, 082 &, 074 & 19,142 \\
\hline \multicolumn{7}{|c|}{ a. Predictors: (Constant), nilai_pendidikan_karakter } \\
\hline
\end{tabular}

Berdasarkan data Model Summary pada tabel.4 dapat diketahui bahwa nilai dari $R$ Squarenya adalah 0,082 yang 
berarti $8,2 \%$. Jadi dapat disimpulkan bahwa variabel nilai pendidikan karakter memberikan pengaruh terhadap disiplin siswa hanya sebesar $8,2 \%$ dan untuk 91,8 $\%$ oleh faktor lain yang tidak dijelaskan dalam penelitian ini.

Tabel 5. Data Anova

\begin{tabular}{|c|c|c|c|c|c|c|}
\hline \multicolumn{7}{|c|}{ ANOVA $^{\mathrm{a}}$} \\
\hline \multicolumn{2}{|c|}{ Model } & Sum of & Df & Mean & $\mathrm{F}$ & Sig. \\
\hline \multirow{3}{*}{1} & $\begin{array}{l}\text { Regress } \\
\text { ion }\end{array}$ & 3768,943 & 1 & 3768,943 & $\begin{array}{l}10,28 \\
5\end{array}$ &, $002^{\mathrm{b}}$ \\
\hline & $\begin{array}{l}\text { Residua } \\
1\end{array}$ & $\begin{array}{l}42139,94 \\
6\end{array}$ & 115 & 366,434 & & \\
\hline & Total & $\begin{array}{l}45908,88 \\
9\end{array}$ & 116 & & & \\
\hline \multicolumn{7}{|c|}{ a. Dependent Variable: disiplin } \\
\hline & & $\overline{\mathrm{ons}}$ & lai & idikan_k & kter & \\
\hline
\end{tabular}

Berdasarkan data Anova pada tabel di atas dapat diketahui hasil nilai $F$ hitung $=10,285$ dengan tingkat probabilitas signifikansi 0,002 dengan derajat kebebasan $(\mathrm{dk})$ penyebut $(\mathrm{n}-\mathrm{m}-1)=116$. Sehingga intuk nilai $\mathrm{F}$ tabelnya dapat diperoleh hasil 3,92 oleh karena itu nilai F hitung lebih besar dibandingkan dengan F tabel $(10,285>3,92)$ maka dapat disimpulkan bahwa terdapat pengaruh secara simultan nilai pendidikan karakter terhadap disiplin siswa.

Sedangkan untuk tingkat probabilitasnya 0,002 sehingga lebih kecil dari $0.05(0,002<0.05)$ maka dapat dikatakan juga bahwa terdapat pengaruh secara simultan nilai pendidikan karakter terhadap disiplin siswa.
Tabel 6. Data Coefficient

\begin{tabular}{|c|c|c|c|c|c|}
\hline \multicolumn{6}{|l|}{ Coefficients $^{\mathrm{a}}$} \\
\hline \multirow[t]{2}{*}{ Model } & \multicolumn{2}{|c|}{$\begin{array}{l}\text { Unstandardized } \\
\text { Coefficients }\end{array}$} & $\begin{array}{l}\text { Standar } \\
\text { dized }\end{array}$ & \multirow[t]{2}{*}{$\mathrm{t}$} & \multirow[t]{2}{*}{ Sig. } \\
\hline & B & $\begin{array}{l}\text { Std. } \\
\text { Error }\end{array}$ & Beta & & \\
\hline (Constant) & 13,943 & 35,746 & & ,390 & ,697 \\
\hline $\begin{array}{l}\text { nilai_pendidik } \\
\text { an_karakter }\end{array}$ & 625 & ,195 & 287 & $\begin{array}{l}3,20 \\
7\end{array}$ & ,002 \\
\hline \multicolumn{6}{|c|}{ a. Dependent Variable: disiplin } \\
\hline
\end{tabular}

tabel di atas, dapat diketahui bahwa $\mathrm{T}$ hitung $=3,207$ dengan tingkat signifikansi 0,002 dan $\mathrm{dk} \quad$ (derajat kebebasan) n-2 yaitu $117-2=115$ dengan menggunakan uji dua pihak sehingga nilai $\mathrm{T}$ tabel $=1,658$, karena nilai $\mathrm{T}$ hitung lebih besar dari $\mathrm{T}$ tabel $(3,207>1,658)$ maka dinyatakan terdapat pengaruh.

Dengan demikian, hipotesis penelitian yang menyatakan bahwa terdapat pengaruh yang signifikan antara nilai pendidikan karakter terhadap disiplin siswa adalah dapat diterima. Artinya, ada pengaruh yang signifikan antara nilai pendidikan karakter terhadap disiplin siswa.

\section{PEMBAHASAN}

Pendidikan karakter merupakan pemberian tuntunan atau upaya yang dilakukan untuk merubah, memperbaiki sikap serta tingkah laku seseorang agar dapat berperilaku yang baik. Di setiap lembaga pendidikan, pendidik juga 
memberikan pendidikan karakter yang berisi tentang nilai-nilai pendidikan karakter kepada para siswa melalui mata pelajaran maupun budaya yang ada disekolah agar siswa dapat membentuk dan mempunyai karakter yang baik sesuai dengan nilai pendidikan karakter yang ditetapkan oleh Kemendikbud (2010).

Hasil penelitian diketahui bahwa variabel nilai pendidikan karakter kelas XI SMK Islam Sudirman tahun ajaran 2018/2019 yang berjumlah 117 siswa dapat diperoleh hasil sebesar 0\% dengan jumlah 0 siswa berada pada kategori sangat baik. Sebesar 35,89\% dengan jumlah 42 siswa berada pada kategori baik. Sebesar 64,10\% dengan jumlah 75 siswa berada pada kategori cukup baik. Sebesar $0 \%$ dengan jumlah 0 siswa pada kategori kurang baik dan 0\% dengan jumlah 0 siswa berada pada kategori tidak baik. Sehingga dapat disimpulkan bahwa siswa kelas XI SMK Islam Sudirman tahun ajaran 2018/2019 tergolong berada pada kategori cukup baik dalam menerapkan nilai pendidikan karakter yang diberikan oleh pendidik yang ada di SMK Islam Sudirman.

Sedangkan pada variabel disiplin siswa kelas XI SMK Islam Sudirman tahun ajaran 2018/2019 yang berjumlah 117 siswa dapat diperoleh hasil sebesar 45,29\% dengan jumlah 53 siswa berada pada kategori sangat tinggi. Sebesar $37,60 \%$ dengan jumlah 44 siswa berada pada kategori tinggi. Sebesar 14,52\% dengan jumlah 17 siswa berada pada kategori sedang. Sebesar 2,56 \% dengan jumlah 3 siswa pada kategori rendah dan $0 \%$ dengan jumlah 0 siswa berada pada kategori sangat rendah. Sehingga, dapat disimpulkan bahwa siswa kelas XI SMK Islam Sudirman tahun ajaran 2018/2019 memiliki disiplin siswa yang tergolong berada pada kategori sangat tinggi.

Masalah yang ingin diungkap dalam penelitian ini adalah apakah ada pengaruh yang signifikan antara nilai pendidikan karkter terhadap disiplin siswa kelas XI SMK Islam Sudirman tahun ajaran 2018/2019.

Berdasarkan data yang diperoleh dari hasil penelitian kemudian diolah dengan menggunakan program SPSS for windows 21.0, dapat dijadikan dasar untuk menjawab hipotesis yang diajukan yaitu "terdapat pengaruh yang signifikan anatara nilai pendidikan karakter terhadap disiplin siswa kelas XI SMK Islam Sudirman tahun ajaran 2018/2019”.

Berdasarkan data model summary dapat diketahui bahwa nilai dari $R$ Squarenya adalah 0,082 yang berarti 8,2 $\%$. Jadi dapat disimpulkan bahwa variabel pendidikan karakter memberikan pengaruh terhadap disiplin siswa hanya 
sebesar 8,2\%, dan untuk 91,8 \% oleh faktor lain yang tidak dijelaskan dalam penelitian ini.

Faktor lain yang mempengaruhi disiplin siswa diantaranya seperti yang diutarakan oleh Semiawan (2009) yaitu hubungan emosional yang kualitatif dan kondusif sebagai landasan untuk membentuk disiplin, keteraturan yang konsisten dan berkesinambungan dalam menjalankan berbagai aturan, keteladanan yang berawal dari perbuatan kecil dalam ketaatan disiplin di rumah, seperti belajar tepat waktu, lingkungan yang berfungsi untuk pengembangan disiplin, baik lingkungan rumah, sekolah dan masyarakat, ketergantungan dan kewibawaan yang harus dimiliki oleh setiap guru dan orang tua untuk memahami dinamisme perkembangan anak.

Selain itu faktor lain yang membentuk disiplin siswa menurut Tu'u (2004) yaitu kesadaran diri sebagai pemahaman diri bahwa disiplin dianggap penting bagi kebaikan dan keberhasilan dirinya, selain itu kesadaran diri menjadi motif kuat terwujudnya disiplin, pengikutan dan ketaatan sebagai langkah penerapan dan praktik atas peraturanperaturan yang mengatr individunya, alat pendidikan untuk mempengaruhi, mengubah, membina, dan membentuk perilaku yang sesuai dengan nilai-nilai yang ditentukan atau diajarkan, hukuman sebagai upaya menyadarkan, mengoreksi dan meluruskan yang salah sehingga orang kembali pada perilaku yang sesuai dengan harapan.

Hasil pengujian hipotesis memperoleh nilai $\mathrm{f}$ hitung pendidikan karakter terhadap disiplin siswa sebesar $(10,285>3.92)$ dan $t$ hitung sebesar $(3,207>1,658)$ dengan signifikansi $=$ 0,002 diterima pada taraf signifikansi 5\% $(0,002<0,05)$. Hal ini membuktikan bahwa ada pengaruh yang signifikan antara nilai pendidikan karakter terhadap disiplin siswa kelas XI SMK Islam Sudirman tahun ajaran 2018/2019.

Di lingkungan sekolah SMK Islam Sudirman juga sudah menunjukkan bagaimana nilai pendidikan karakter yang sudah diimplementasikan kepada para siswa seperti melalui berbagai kegiatankegiatan yang ada disekolah serta melalui mata pelajaran yang dapat membentuk dan mengembangkan karakter peserta didik terutama dalam mendisiplinkan diri.

Disiplin adalah sikap seseorang untuk mentaati aturan atau tata tertib yang berlaku di dalam suatu organisasi berdasarkan kesadaran yang ada pada dirinya untuk membentuk perilaku yang sesuai dengan nilai-nilai yang ditentukan. Implementasi pendidikan karakter yang 
diterapkan disekolah seperti adanya kegiatan senyum salam sapa setiap pagi, kegiatan literasi 15 menit sebelum memulai pelajaran, membaca asmaul husna sebelum memulai pelajaran, cek kerapian seragam setiap pagi, rutinitas sholat jumat serta adanya kantin kejujuran untuk mengajarkan siswa bersikap jujur.

Dengan demikian, diharapkan para siswa bisa menerapkan nilai pendidikan karakter dalam kehidupan sehari-hari di sekolah maupun diluar sekolah terutama dalam mendisiplinkan diri, karena dengan mempunyai disiplin diri yang baik maka akan tercipta sumber daya manusia yang berkualitas. Selain itu tujuan dari pendidikan karakter adalah membentuk, menanamkan, memfasilitasi, dan mengembangkan nilai-nilai positif pada anak sehingga menjadi pribadi yang unggul dan bermartabat (Agus Zaenul Fitri, 2012).

\section{PENUTUP}

\section{Simpulan}

Berdasarkan hasil penelitian dan pembahasan yang telah dilakukan, dapat diambil kesimpulan bahwa terdapat pengaruh yang signifikan antara nilai pendidikan karakter terhadap disiplin siswa kelas XI SMK Islam Sudirman Tahun Ajaran 2018/2019.

\section{Saran}

Berdasarkan kesimpulan di atas, maka peneliti mengajukan beberapa saran sebagai tindak lanjut dari penelitian ini sebagai berikut:

Berdasarkan hasil penelitian yang menujukkan bahwa nilai pendidikan karakter mempunyai pengaruh terhadap disiplin siswa maka diharapkan siswa dapat mempunyai sikap disiplin sehingga dapat mempunyai karakter yang baik dengan cara mendisiplinkan diri sendiri.

Berdasarkan hasil penelitian yang menunjukkan bahwa nilai pendidikan karakter mempunyai pengaruh dalam disiplin siswa maka untuk guru bimbingan dan konseling dapat memberikan layanan bimbingan dan konseling yang memuat tentang nilai pendidikan karakter sehingga peserta didik dapat mengimplementasikan pendididikan karakter sesuai dengan 18 nilai-nilai pendidikan karakter.

Bagi peneliti selanjutnya yang berminat untuk meneliti mengenai variabel yang sama maupun subjek yang sama, diharapkan dapat mengkaji lebih mendalam dengan melibatkan variabelvariabel lain yang berhubungan dengan disiplin siswa seperti keteladanan, kesadaran diri dan lain sebagainya. 


\section{DAFTAR PUSTAKA}

Adisusilo, Sutarjo. 2012. Pembelajaran Nilai - Karakter: Konstruktivisme dan VCT Sebagai Inovasi Pendekatan Pembelajaran Afektif, Jakarta: PT Raja Grafindo Persada.

Arikunto, Suharsimi. 2010. Manajemen Penelitian. Jakarta: Rineka Cipta.

Aqib,Zainal. 2012. Pendidikan Karakter Disekolah Membangun Karakter Dan Kepribadian Anak. Bandung: Yrama Widya

Azwar, Saifudin. 2012. Penyusunan Skala Psikologi.Yogyakarta: Pustaka Pelajar

Elfachmi, Amin Kuneifi. 2016. Pengantar Pendidikan. Jakarta: Erlangga.

Gunawan, Heri. 2012. Pendidikan Karakter Konsep Dan Implementasi. Bandung: Alfabeta.

Hurlock, Elizabeth B. 2002. Perkembangan Anak. Jakarta: Erlangga.

Imron, Ali. 2011. Manajemen Peserta Didik Berbasis Sekolah. Jakarta: Bumi Aksara.

Kurniawan, Syamsul. 2013. Pendidikan Karakter: Konsepsi Dan Implementasinya Secara Terpadu Di Lingkungan Keluarga, Sekolah, Perguruan Tinggi Dan Masyarakat. Yogyakarta: Ar-Ruzz Media.

Lickona, Thomas. 2012. Pendidikan Karakter. Bantul: Kreasi Wacana.

Muslich, Masnur. 2011. Pendidikan Karakter: Menjawab Tantangan Krisis Multidimensional. Jakarta: Bumi Aksara
Narwanti, Sri. 2011. Pendidikan Karakter Pengintegrasian $18 \quad$ Nilai Pembentuk Karakter Dalam Mata Pelajaran. Yogyakarta: Familia

Rawambaku, Rambu Mbangi. 2006. Kedisiplinan Dalam Pendidikan. Salatiga: Widya Sari

Sadulloh, Uyoh. 2014. Pengantar Filsafat Pendidikan. Bandung: Penerbit Alfabeta

Samani, Muchlasin Dan Hariyanto. 2011. Konsep Dan Model Pendidikan Karakter. Bandung : Pt Remaja Rosdakarya

Semiawan, Conny R. 2009. Penerapan Pembelajaran Pada Anak. Jakarta: Pt Indeks

Sugiyono. 2015. Metode Penelitian Kombinasi (Mixed Methods). Bandung : Alfabeta.

Sugiyono. 2011. Statistika Untuk Penelitian. Bandung: Alfabeta.

Tu'u,Tulus. 2004. Peran Disiplin Pada Perilaku Dan Prestasi Siswa. Jakarta : Grasindo.

Unaradjan, Dolet. 2003. Manajemen Disiplin. Jakarta : Grasindo

Wicaksono, Andri. 2014. Pengkajian Prosa Fiksi. Yogyakarta: Garudhawaca. 